This report was prepared as an account of work sponsored by an agency of the United States Government. Neither the United States Government nor any agency thereof, nor any of their employees, makes any warranty, express or implied, or assumes any legal liability or responsibility for the accuracy, completeness, or usefulness of any information, apparatus, product, or process disclosed, or represents that its use would not infringe p.ivately owned rights. Reference berein to any specific commercial product, process, or service by trade name, trademark, manufacturer, or otherwise does not necessarily constitute or imply its endorsement, recommendation, or favoring by the United States Government or any agency thereof. The views and opinions of authors oxpressed herein do not necessarily state or reflect those of the United States Government or any agency thereof.

\title{
Iron and Manganese in Oxide Minerals and in Glasses: Preliminary Consicieration of Eh Buffering Potential at Yucca Mountain, Nevada
}

\author{
F. A. Caporuscio* \\ D. T. Vaniman
}

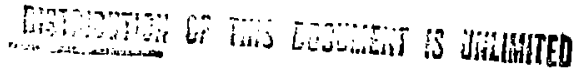


IRON AND MANGANESE IN OXIDE MINERALS AND IN GLASSES:

PRELIMINARY CONSIDERATION OF Eh BUFFERING POTENTIAL AT YUCCA MOUNTAIN, NEVADA

by

F. A. Caporuscio and D. T. Vanir an

\section{ABSTRACT}

The tuffs of Yucca Mountain at the Nevada Test Site are currently under investigation as a possible deep burial site for highlevel radioactive waste disposal. One of the main concerns is the effect of oxidizing groundwater on the transport of radionuclides. Rock components thiat may affect the oxygen content of groundwater include Fe-Ti oxides, Mn oxides, and glasses that contain ferrous iron.

Some phenocryst Fo-Ti oxides at Yucca Mountain are in reduced states, whereas groundmass $\mathrm{Fe}-\mathrm{Ti}$ oxides have been oxidized to hematite. rutile, and pseudobrookite ( $\mathrm{Fe}^{{ }^{+}}$-bearing phases) exclusively. Estimates of $\mathrm{F}^{2}{ }^{+}$-bearing oxides indicate that less than 0.33 vol\% phenocrystc is available to act as solid buffering agents of Eh. Of this percentage, significant amounts of Fe-Ti oxides are isolated from effective interaction with groundwater because they occur in densely welded, devitrified tuffs that have low interstitial permeability.

Manganese oxides occur primarily along fractures in the ashflow tuffs. Becriuse the Mn oxides are concentrated along the same pathways (fractures) where transport has occurred in the past, these small volume percentages could act as buffers. However, the oxidation states of actual Mn-oxide phases are high $\left(\mathrm{Mn}^{4+}\right)$, and these minerals have virtually no potential for reducing groundwater Eh. Manganese oxides may even act as oxidizing agents. However, regardless of their poor capabilities as reducing agents, the Mn oxides could be important as sorbents of heavy metals at Yucca Mountain. The lack of accessible, pristine $\mathrm{Fe}-\mathrm{Ti}$ oxides and the generally high oxidation states of Mn oxides seem to rule out these oxides as Eh buffers of the Yucca Mountain groundwater system. Reduction of ferrous iron within glassy tuffs may have some effect on Eh, but further study is needed. At present it is prudent to assume that minerals and glasses have little or no capacity for reducing oxygen-rich groundwater at Yucca Mountain. 


\section{INTRODUCTION}

The southwestern portion of the Nevada Test Site (NTS) in south-central Nevada is being studied to aetermine the suitability of the area for an underground high-level waste repository. This report is one of the continuing studies, sponsored by the Nevada Nuclear Waste Storage Investigations (NNWSI), concerned with the tuff units of Yucca Mountain and the suitability of these units for waste isolation. The NNWSI Project is managed by the Nevada Operations office of the Department of Energy. The exploration drill holes mentioned in this report (USW G-1, G-2, G-3, GU-3, G-4, USW H-6, UE-25p\#1, UE-25a\#1, and UE-25b\#1) are on or near Yucca Mountain near the southwest border of the NTS (Fig. 1). The Yucca Mountain block is composed of a thick sequence of ash-flow tuffs, lavas, and bedded tuffs that have been derived primarily from the Timber Mountain-Oasis Valley caldera complex (Byers et al. 1976; Christiansen et a1. 1977). The thickness of tuffs at Yucca Mountain exceeds $6000 \mathrm{ft}(1830 \mathrm{~m})$ and may extend to $10000 \mathrm{ft}(3050 \mathrm{~m})$. The tuffs range in age from 15 to 12 Myr.

Oxide minerals (also referred to as "opaques" because of their optical properties) can remove oxygen from groundwater if the oxide minerals contain oxidizable $\mathrm{Fe}^{2+}$ or $\mathrm{Mn}^{2+}$. The primary objective of this report is to estimate the distribution and volume percentages of $\mathrm{Fe}^{2+}$-bearing oxide minerals in the Yucca Mountain block. If present in sufficient abundance, these minerals (magnetite and ilmenite) could buffer groundwater oxygen content at Yucca Mountain. Several waste radionuclides have lower solubilities under reducing conditions thari under oxidizing conditions, e.g., Tc, U, Np, Pu (Ogard and Kerrisk 1984). This work is primarily to determine whether enough Fe 0 is accessible in the Yucca Mountain block to efficiently buffer the water Eh and thereby limit the solubilities of such waste elements. The Fe-Ti oxides occur as both phenocrysts and groundmass grains. This report discusses which Fe-Ti oxides are in a pristine (reduced) form and presents oxidation-exsolution data for these oxides (Appendix A). Zones of high-and low-Fe-Ti-oxide cxidation are also discussed in this paper, with particular emphasis on low-oxidation zones.

A secondary objective of this report is to identify the types and abundances of $\mathrm{Mn}$ oxides that are concentrated in tuff fractures (open and closed) at vucca Mountain. These variable-composition oxides have limited potential as groundwater buffers but may provide additional sorption within 

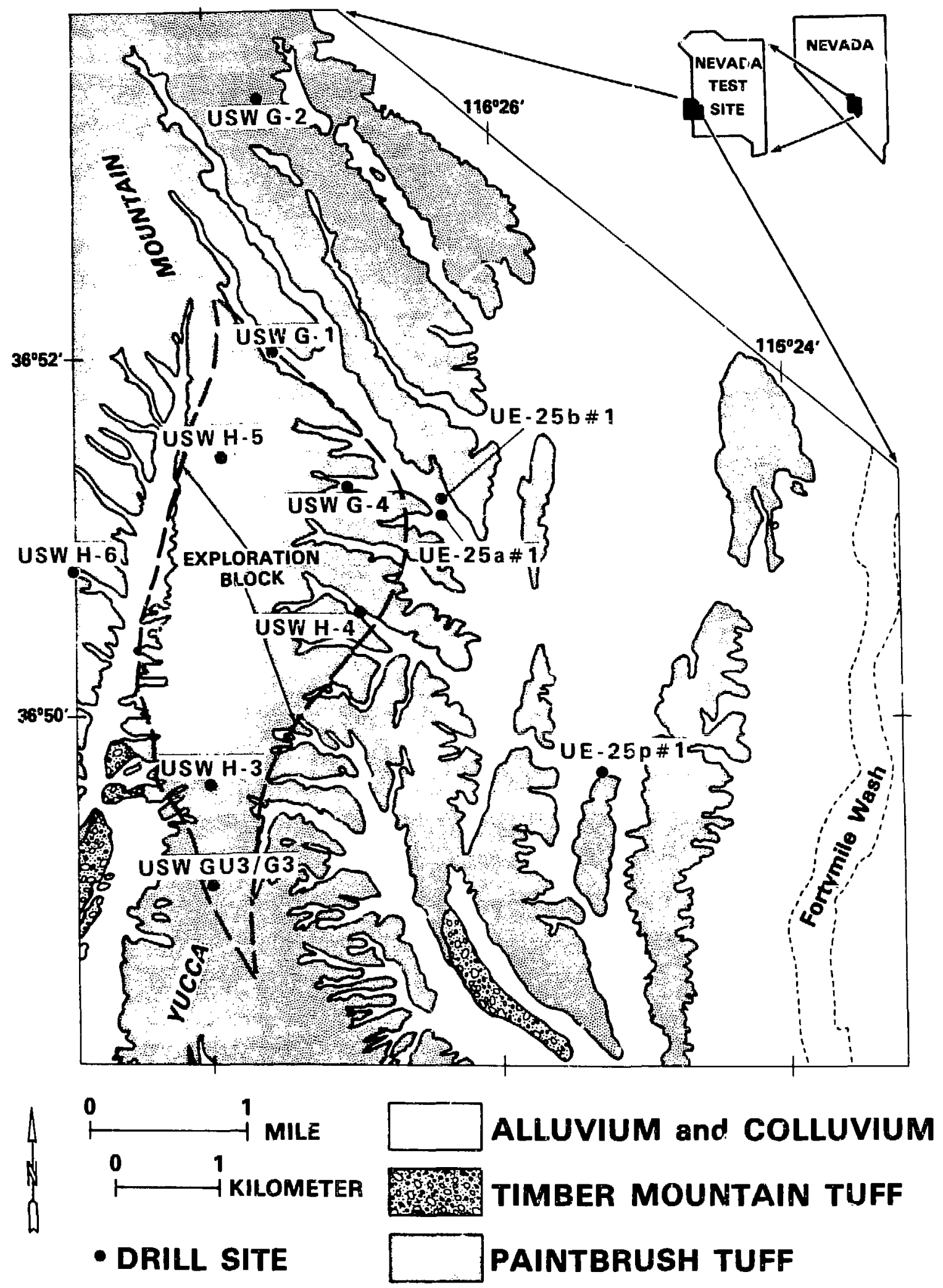

Fig. 1. Index map of Yucca Mountain, including pertinent dril1 holes. 
fractures. The source of Mn for Mn fracture fill is discussed in Sec. $V$ of this paper.

\section{METHODS}

Both cubic and rhombohedral Fe-ri oxifes are ubiquitous in the tuffs and rarer lavas of Yucca Mountain. These oxides are useful because they reflect the extent of groundwater-tuff interaction, the permability of the enclosing rocks, and the maximum oxidation state of the rock (see Bish et al. 1981; Caporuscio et al. 1982). Haggerty (1976a) developed an empirical method, using reflected-light microscopy, to evaluate the oxidation state of Fe-Ti-oxide phenocrysts in basalts. His method of evaluating and characterizing oxidation exsolution textures in Fe-Ti oxides (Table I) has been adapted to our investigation of high-silica rocks.

The Fe-Ti oxides are observed as microphenocrysts and as alteration products in the ash flows and lavas. Morphologies irdicate that both cubic [magretite-ülvospinel solid-solution series (Mt-üspss)] and rhombohedral [ilmenite-hematite solid-solution series (I1m-Hem $\left.\left.{ }_{s s}\right)\right]$ phases exist. Subsequent oxidation of the Fe-Ti oxides after eruption produced a series of oxidation-exsolution phases within the original grains. Haggerty's (1976a) classification for the cubic $\left(C_{1}\right.$ to $\left.C_{7}\right)$ and rhombohedral $\left(R_{1}\right.$ to $\left.R_{7}\right)$ phases is retained for this study, where subscript 1 denotes the unoxidized phase and subscript 7 denotes complete oxidation of the phase. In all cases, the oxidation state of the Ilm-Hem closely parallels that of the Mt-üsp ${ }_{s s}$. Therefore, all oxides reported are given a $C_{x}$ notation for consistency. The oxidation siate of the Fe-Ti uxides depends on the highest ambient $\mathrm{fO}_{2}$ (oxygen fugacity), which may often be correlated with the interstitial permeability and degree of welding of the tuffs. It is important to differentiate transmissibility, which may be high in densely welded fractured tuffs and low in nonwelded tuffs, and the interstitial permeability that is generally low in densely welded tuff but high in nonwelded tuff (Winograd and Thordarson 1975). In nonwelded tuffs (high interstitial permeability), the Fe-Ti oxides are generally oxidized $\left(C_{5}-C_{7}\right)$. Densely welded tuffs (low interstitial permeability) generally record low oxidation states $\left(C_{1}-C_{3}\right)$. Because of oxidation-exsolution kinetics, the retrograde process is extremely sluggish; therefore, the oxidation state recorded is the nighest oxygen fugacity obtained and does not always indicate the present oxygen fugacity in the tuffs. 
TABLE I. EXSOLUTION OXIDATION OF FE-Ti OXIDE CUBIC AND RHOMBOHEDRAL PHASES

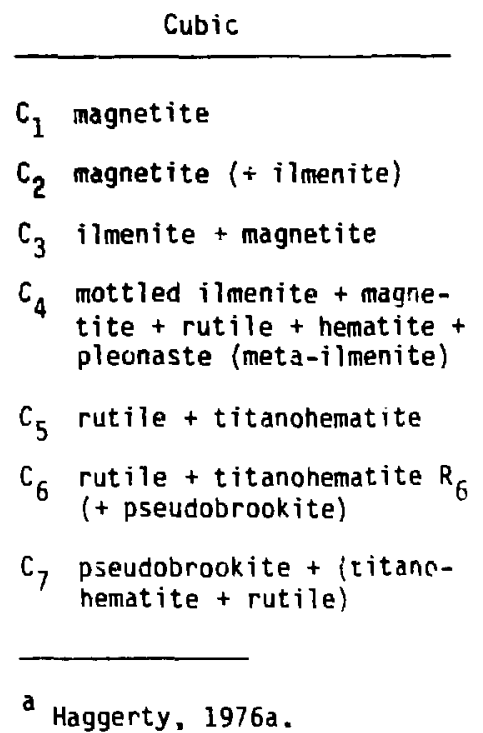

\begin{tabular}{|c|c|}
\hline & Rhombohedral \\
\hline$R_{1}$ & ilmenite \\
\hline$R_{2}$ & ilmenite + rutile \\
\hline$R_{3}$ & rutile + ilmenite \\
\hline$R_{4}$ & $\begin{array}{l}\text { rutile + titanohematite }+ \\
\text { ferrian rutile + ferrian ilmenite }\end{array}$ \\
\hline$R_{5}$ & rutile + titanohematite \\
\hline$R_{6}$ & $\begin{array}{l}\text { rutile }+ \text { titanohematite }+ \text { (pseudo- } \\
\text { brookite) }\end{array}$ \\
\hline $\mathrm{R}_{7}$ & $\begin{array}{l}\text { pseudobrookite + (rutile + titano- } \\
\text { hematite) }\end{array}$ \\
\hline
\end{tabular}

Major exceptions to the scheme described above occur in rocks containing sulfides, carbonates, or vapor-phase alteration. For example, in the densely welded portion of the Topopah Spring Member where vapor-phase minerals are present, the oxidation state varies greatly. This occurs because vapor-phase fluids have high water content and therefore have a high oxygen fugacity. oxidation state is controlled by vapor-phase fluids that may intersect a particular grain. In many samples, oxide grains in proximity can have radically different oxidation states. In rocks containing sulfides or carboriates, oxygen fugacity is decreased and the oxidation of Fe-Ti-oxide minerals is retarded. Either of these fluids ( $\mathrm{S}$ - or $\mathrm{CO}_{2}$-bearing) would have a much lower $\mathrm{fO}_{2}$ than one bearing $\mathrm{H}_{2} \mathrm{O}$ only. Therefore, these fluids may oxidize the Fe-Ti oxides but to a lesser extent. Specific examples are given in Sec. III of this report.

The content of ferrous iron in bulk-rock samples is discussed in Sec. VII. Determinations of ferrous iron were made by the method of Bower (1984), based on spectrophotometric determination. The precision of this method is better than $0.2 \mathrm{wt} \% \mathrm{Fe}$.

III. OXIDES WITHIN THE YUCCA MOUNTAIN BLOCK

During this study, over 430 polished thin sections of tuff and lava from nine drill holes were examined by reflected-light microscopy for Fe-Ti-oxide 
phenocrysts. Between 10 ail:: 20 phenocrysts were characterized for oxidation exsolution in each thin section. The average oxidation state is the sum of the individual oxidation-state values divided by the number of oxides examined in a thin section. These average oxidation states are summarized in Fig. 2 for all nine drill holes. More detailed information on the oxidation state of Fe-Ti oxides can be obtained from the appropriate drill-hole characterization report (Bish et al. 1981; Carroll et al. 1981; Caporuscio et al. 1982; Vaniman et a1. 1.984) and from Appendix A. Most consistent trends, however, are apparent. in Fig. 2 .

Regions in the tuffs and lavas of Yucca Mountain that have an average oxidation state of $\mathrm{C}_{4}$ or less are deficted by a stippled pattern in Fig. 2. The reason for highlighting these regions is the presence of $\mathrm{Fe}^{2+}$ in the cubic (Mt-Usp $\mathrm{ss}_{\mathrm{s}}$ ) and, rhombohedral (Ilm-Hem $\mathrm{ss}$ ) opaques. The regions thus depicted still cortain magnetite $\left(\mathrm{Fe}^{2+} 0: \mathrm{Fe}_{2}^{3+} \mathrm{O}_{3}\right)$ and ilmenite $\left(\mathrm{Fe}^{2+} \mathrm{TiO}_{3}\right)$ in varying quantities. Significant quantities of iron in the reduced state could buffer water in the Eh range of -0.2 to $0.0 \mathrm{~V}$ for $\mathrm{pH}$ in the range from 6 to 8 (Garrels and Christ 1965).

Figure 2 lists numerous zones where the average oxidation state is less than or equal to four. These zones occur in both the saturated and unsaturated zones of Yucca Mountain. Unoxidized opaques are not expected in the saturated zones because of water interaction; therefore, these low-oxidation zones require explanation. We noted earlier that $\mathrm{S}$ - and $\mathrm{CO}_{2}^{-}$ bearing fluids suppress the oxidation state of Fe-ii oxides (Caporuscio et al. 1982). Clear examples are seen in drill cores USW G-2, UE-25a\#1/b\#1, and USW G-3/GU-3 (Fig. 2). In those zones with sulfides, the oxides are relatively unoxidized compared with surrounding tuff units. Similarly, carbonate-rich zones in USW G-1 ( $\backsim 5200-6000 \mathrm{ft})$ and UE-25p\#1 ( $3700-3800 \mathrm{ft})$ exhibit suppressed oxidation states $\left(\mathrm{C}_{4}\right.$ or less). Another environment in the saturated zone where Fe-Ti-oxide phenocrysts are commonly $C_{4}$ or less is in dacitic to rhyolitic lavas. These lavas and their associated slightly oxidized opaques are readily apparent in USW G-1 ( $n 3350-3900 \mathrm{ft}$ ) and in USW G-2 (5000 to $5200 \mathrm{ft}$ and 5650 to $6000 \mathrm{ft}$ ). Opaques in the lavas are only slightly oxidized due to the low permeability of the flows. The remaining low-oxidation region in the saturated zone ( 1900 to $2100 \mathrm{ft}$ in USW G-1) is caused by very low interstitial permeability in the densely welded zone of the Prow Pass member of the Crater Flat Tuff. 


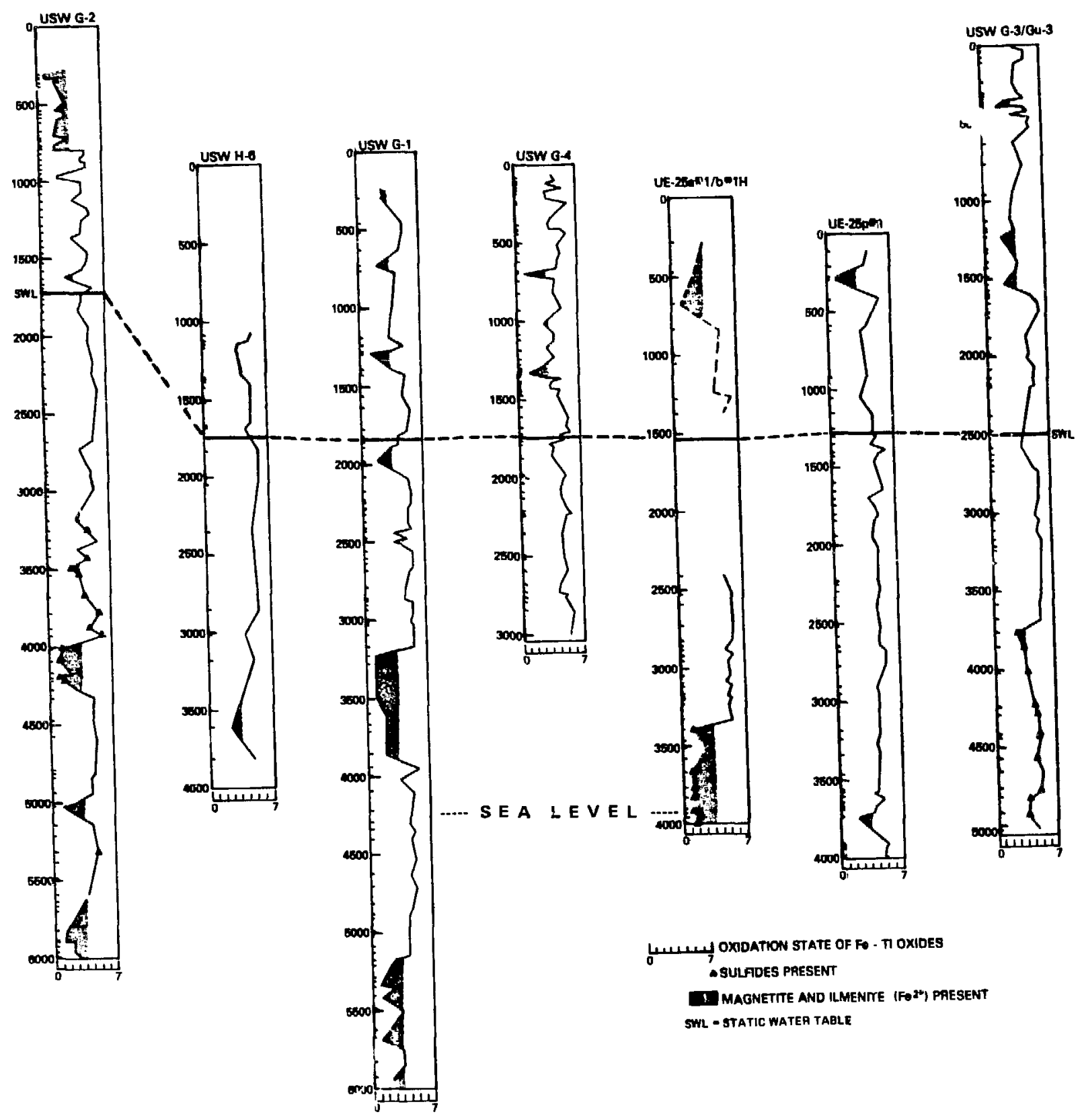

Fig. 2. Oxidation states of Fe-Ti oxides at Yucca Mountain. Note that oxidation state increases from left to right and that shaded regions are less than or equal to $C_{4}$. Depths from surface (in feet) are 7 isted along each column; columns are justified to datum for lateral comparison. 
All other regions where the Fe-Ti-oxide phenocrysts still retain some primary magnetite or ilmenite are in the unsaturated zone at Yucca Mountain. Specifically, all nonoxidized zones are associated with either the upper and lower vitrophyres of the Topopah Spring member (for example, $400 \mathrm{ft}$ and 1300-1400 ft of USW G-3) or with densely welded zones ( $700 \mathrm{ft}$ in G-4, uppermost G-2,, $750 \mathrm{ft}$ in $\mathrm{G}-1$, and $500-600 \mathrm{ft}$ in $U E-25 \mathrm{a \# 1}$ ). The only exception is at approximately $1500 \mathrm{ft}$ in drill core USW G-3/GU-3. In this instance, the nonoxidized opaques occur in the nonwelded, unaltered vitric tuff of Calico Hills above the static water level. All other non- to slightly oxidized opaques in the unsaturated zone are in densely welded tuff of low interstitial permeability.

\section{ESTIMATION OF $\mathrm{Fe}^{2+}$ REMAINING IN Fe-Ti OXIDES AT YUCCA MOUNTAIN}

Using the Fe-Ti-oxide mineral oxidation-exsolution studies of the drill cores presented in Fig. 2, we attempted to estimate the amount of magnetite and ilmenite remaining at Yucca Mountain. This estimate was based on three assumptions. First, we assumed that the modal abundances of oxides in the USW G-1 core were reasonable estimates of the volume of oxides in the Yucca Mountain block as a whole. That is, we assumed that the relative volume of oxides in an ash-flow tuff has little lateral variability. We further assumed that USW G-1 is representative of overall mineralogy, and its proximity to the exploration block will certainly produce data pertinent to that region. Second, two researchers have produced different modal abundances for opaques in USW G-1 and these values were used as upper and lower limits. Byers et al. (1976) reported 1.64 modal\% opaques (upper limit), whereas Caporuscio et al. (1982) reported 0.90 modal\% opaques (lower limit) in USW G-1. And third, we assumed that we could make a reasonable estimate of the amount of ilmenite and magnetite in oxidized opaques.

As can be seen in Table I, there is no ilmenite or magnetite in phenocrysts denoted by $R_{5}$ to $R_{7}$ or $C_{5}$ to $C_{7}$. In the case of $C_{4}$, the grain contains about $40 \%$ magnetite plus ilmenite, whereas $R_{4}$ has approximately $25 \%$ ilmenite. The remainder of the $C$ series $\left(C_{1}\right.$ to $C_{3}$ ) describes a progressive transition from $\mathrm{Ti}$-rich magnetite $\left(\mathrm{Fe}_{2}^{2+} \mathrm{Ti}\right)$ to $\mathrm{Ti}$-poor magnetite $\left(\mathrm{Fe}^{2+} \mathrm{Fe}_{2}^{3+}\right)$, along with the formation of exsolved ilmerite $\left(\mathrm{Fe}^{2+} \mathrm{Ti}\right)$ in supplementary proportions. This oxidation series can be described as follows: $C_{1}=100 \% \mathrm{Mt}, \mathrm{C}_{2}=75 \% \mathrm{Mt}$, $25 \% \mathrm{Ilm}, \mathrm{C}_{3}=50 \% \mathrm{Mt}, 50 \% \mathrm{I} \mathrm{m}$. For the rhombohedral series, any oxidation 
results in a loss of $\mathrm{Fe}^{2+}$-bearing ilmenite to produce rutile and titanohematite, or pseudobrookite. The examples are as follows: $R_{1}=100 \% \mathrm{Ilm}, R_{2}$ $=75 \% \mathrm{Ilm}, \mathrm{R}_{3}=50 \% \mathrm{Ilm}$, and $\mathrm{R}_{4}=25 \% \mathrm{Ilm}$. These percentages are used to generate columns 3 and 4 in Table II.

To calculate the volume percentage of $\mathrm{Fe}^{2+}$-bearing opaques (magnetite and ilmenite) at Yucca Mountain, we combined the assumptions stated previously about modal percentages and ratios of ilmenite and magnetite (that is, $R_{3}=$ $50 \%$ ilmenite) to set both 1ower and upper limits. In Table II, column 1 is the percentage of samples with an average oxidation state of $C_{4}$ (or $R_{4}$ ) or less. These sampies range from a high of $40 \%$ in USW G-2 to a low of $15 \%$ in UE-25p\#1, with an average of $29 \%$ for the Yucca Mountain block. Column 2 indicates the maximum possible volume percentage of oxides if all opaques are magnetite, if those phenocrysts are unoxidized, and if the volume percentage of oxides used is 0.90 modalo rvalue from Caporuscio et al. (1982) for USW G-1.1. The only change in column 3 is that $C_{4}$ oxides are now weighted at $40 \%$ $\mathrm{Fe}^{2+}$-bearing phases. Therefore, all samples that have an average oxidation state of $\mathrm{C}_{4}$ contain only $40 \%$ magnetite plus ilmenite in their phenocrysts. Column 3 indicates that if all Fe-Ti oxides in the Yucca Mountain block were originally 0.90 vol\% magnetite, only 0.23 vol\% remains because of subsequent oxidation. Similarly, column 4 reports calculations assuining that all opaques were originally ilmenite phenocrysts. By using the percentages in column 2 and factoring in the percentage of i imenite lost to oxidation, we obtained the results in column 4 . The oxidation factor for ilmenite was discussed previous?y (that is, $R_{i}=100 \%$ ilmemite, $R_{2}=75 \%$ ilmenite, $25 \%$ rutile, etc.). This correction facton takes into account the fact that an $R_{2}$ phenocryst contains only $75 \%$ by volume of an $\mathrm{Fe}^{2+}$-bearing phase, with further losses for $R_{3}$ and $R_{4}$. The average value of remaining ilmenite (assuming ilmenite phenocrysts only and 0.9 modal\% opaques) in Yucca Mountain is 0.14 vol\%.

We calculated columns 3 and 4 for simplicity; however, it would be wrong to believe that the opaque phenocrysts in the tuffs and lavas of Yucca Mountain were originally either magnetite or ilmenite only. Based on petrographic observations of Yucca Mcuntain samples, phase equilibria studies (Haggerty 1976b), and studies of other suites of rhyolitic rocks (Lipman 1971; Hildreth 1979), we concluded that magnetite and ilmenite phenocrysts originally occurred in approximately equal proportions. This has been taken into account in column 5. The values listed are the averages of numbers for 
TABLE II. VAlUES TO CALCULATE REMAINing Fe ${ }^{2+}$-BEARING OXIDE Minerals at yuCCA MOUNTAIN

\begin{tabular}{|c|c|c|c|c|c|c|}
\hline & $1^{a}$ & $2^{b}$ & $3^{c}$ & $4^{d}$ & $5^{e}$ & $6^{f}$ \\
\hline USH G-1 & $35 \%$ & $0.32 \%$ & $0.27 \%$ & $0.18 \%$ & $0.225 \%$ & $0.41 \%$ \\
\hline USW G-2 & 40 & 0.36 & 0.31 & 0.22 & 0.265 & 0.48 \\
\hline USW G-3 & 27 & 0.25 & 0.21 & 0.09 & 0.15 & 0.27 \\
\hline USH G-4 & 33 & 0.30 & 0.26 & 0.11 & 0.185 & 0.337 \\
\hline USW $H-6$ & 21 & 0.19 & 0.16 & 0.05 & 0.105 & 0.19 \\
\hline$U E-25 b \# 1$ & 30 & 0.30 & 0.26 & 0.26 & 0.26 & 0.47 \\
\hline UE-25p\#1 & 15 & 0.14 & 0.12 & 0.06 & 0.09 & 0.16 \\
\hline Average & $29 \%$ & $0.27 \%$ & $0.23 \%$ & $0.14 \%$ & $0.183 \%$ & $0.331 \%$ \\
\hline
\end{tabular}

\footnotetext{
a Percentage of samples with average oxidation state of $C_{4}$ or less.

b Maximum volume percentage of unoxidized magnetite (0.9 modal\% opaques).

c Calculated volume percentage if magnetite only (0.9 modal\% opaques).

${ }^{d}$ Calculated volume percentage if ilmenite only ( 0.9 modal\% opaques).

e Calculated volume percentage (lower limit), assuming magnetite and ilmenite phenocrysts were originally of equal proportion at time of eruption (0.9 modal\% opaques).

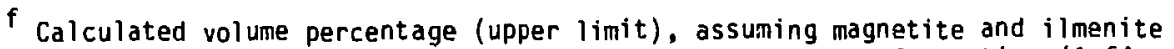
phenocrysts were originally of equal proportion at time of eruption (1.64 modal\% opaques).
}

each drill core from columns 3 and 4 . The volume percentages 1isted in column 5 are the most reasonable estimates for the remaining available $\mathrm{Fe}^{2+}$-bearing phases, ilmenite and magnetite [assuming a lower limit of 0.9 modal\% opaques as calculated by caporuscio et al. (1982)]. The average value listed in column $5(0.18 \mathrm{vol} \%)$ is the lower estimate of available ilmenite and magnetite of the Yucca Mountain block. Column 6 values were calculated using the 1.64 moda1\% of opaques as determined by Byers et al. (1976) for the USW G-1 core samples. For column 6 , the average value ( 0.33 modal\%) is a reasonable upper estimate of available $\mathrm{Fe}^{2+}$-bearing phases for potential buffers.

By analyzing Fe-Ti-oxide phenocryst oxidation and by using the above calculations, we have estimated volume percentages of magnetite and ilmenite available at Yucca Mountain to act as solid buffers. However, these estimates do not represent fully useful $\mathrm{Fe}^{2+}$ unless all oxide phenocrysts were available to the groundwater for interaction. Obviously that assumption is not true, and therefore the amount of $\mathrm{Fe}^{2+}$-bearing oxide phases truly available to react 
with groundwater as a buffer at Yucca Mountain must be less than the higher estimate of 0.33 modal\%. Because most oxides still available for oxidation are above the static water level or are isolated from water in densely welded tuffs and lavas, possibly less than half of the oxides $(0.16 \%)$ are available as solid buffers. Therefore, it is very unlikely that oxide pienocrysts can still buffer groundwater En. Moreover, the more readily available groundmass oxide minerals are already oxidized and therefore are ineffective in controlling Eh. In 430 samples observed so far, we have not yet identified any groundmass oxides as magnetite or ilmenite. The common oxides observed in the groundmass are hematite, goethite and rutile, none of which contains significant $\mathrm{Fe}^{2+}$. Originally, these groundmass oxides were probably magnetite and ilmenite that have been subsequently oxidized. Their rapid oxidation is due to large surface area per volume area (that is, extremely small size) and the ability of water to interact with these small grains. In addition, many of these groundmass oxides are located along grain boundaries where water can interact with the oxides more efficiently. Finally, some groundmass oxides are produced during vapor-phase alteration under high $\mathrm{f0}_{2}$ conditions. In conclusion, the only Fe-Ti oxides capable of acting as a solid buffer at Yucca Mountain are phenocrysts that make up less than 0.33 moda $\%$ of the rock mass and are largely removed from interaction with groundwater.

V. Mn OXIDES: THEIR OCCURRENCE AND ABUNDANCE

The Mn oxides are a diverse series of minerals in which Mn can take on complex oxidation states. Potter and Rossman (1979a) have identified more than 20 valid species of tetravalent and trivalent manganese oxides. These oxides can have varying amounts of water in their structure and have $\mathrm{Mn}$ ionic charges of $2+, 3+, 4+, 6+$, and $7+$ in many combinations. However, Potter and Rossman (1979a) show that most of the Mn-bearing minerals that occur as dendrites in rock fractures contain $\mathrm{Mn}^{4+}$ as the dominant oxidation state. In a study of manganese dendrites, Potter and Rossman (1979b) identified most fracture-lining dendrites as todorokite, romanechite, or a hollandite-group manganese oxide (for example, cryptomelane). They also identified most underground manganese dendrites as todorokite. Potter and Rossman (1979b) found no dendrites with pyrolusite mineralogy and suggested that the term "pyrolusite dendrite" be discontinued. 
The Mn-oxide minerals identified at Yucca Mountain are among those that Potter and Rossman (1979b) specify as being typical of manganese dendrites. Todorokite $\left[(\mathrm{Mn}, \mathrm{Ca}, \mathrm{Mg})^{2+} \mathrm{Mn}_{3}^{4+} \mathrm{O}_{7} \cdot \mathrm{H}_{2} \mathrm{O}\right]$ has been identified in the Tram Member in drill core UE-25b\#1H (Caporuscio et al. 1982). and cryptomelane $\left[\mathrm{KMn}_{8}^{4+, 3+} 0_{16}\right]$ has been identified in the Tram Member of drill core USW G-3 (Vaniman et al. 1984) and in recerit studies of drill core USW G-4 (Fig. 3). Within the Topopah Spring Member of USW GU-3, we used x-ray diffraction studies to identify a Mn-oxide structure that is either lithiophorite [(Ai, Li) $\mathrm{Mn}^{4+} \mathrm{O}_{2}(\mathrm{OH})_{2}$ ] or todorokite. Further work will be done to characterize and interpret the Mn-oxide occurrences at Yucca Mouritain, but the analyses available and the studies by Potter and Rossman (1979a, 1979b) of similar Mn.oxide dendrites strongly suggest that $\mathrm{Mn}^{2+}$ is a minor component or absent in these oxides. Moreover, manganese oxides with $\mathrm{Mn}^{2+}$ would buffer water Eh in a higher range than would iron. Depending on the actual minerals present, Eh could be controlled in the 0.2- to 0.5-V range for pit in the range from 6 to 8 (Garrels and Christ, 1965). For this reason, water buffered by $\mathrm{Mn}^{2+}$ would not be as effective in limiting the solubility of waste elements such as uranium as wouid water buffered by iron. This factor, plus the relative unavailability of $\mathrm{Mn}^{2+}$ in either primary or secondary minerals along the flow path, rules out any effective reduction of groundwater $\mathrm{Eh}$ by $\mathrm{Mn}^{2+}$ at Yucca Mountain.

Of related interest, Zielinski (i983) and Zielinski et al. (1980) have cited hydrated Mn oxides as very strong sorbers of radionuclides and have proposed that $\mathrm{Mn}$ oxides in fractures may be a barrier to radionuclide migration. Concentrations of trace elements such as As, Y, and Ce have been found in Mn oxides of the Topopah Spring Member (Vaniman et al. 1984), indicating that these oxides have accumulated petrologically incompatible elements.

Zielinski (1983) performed whole-rock analyses of all major ash flows and lavas at Yucca Mountain. Values for bulk-rock MnO range from $<0.02 \mathrm{wt} \%$ in the tuff of Calico Hills to 0.32 wt\% in the Tram Member, with an average value of $0.06 \mathrm{wt} \%$. Three likely sources of Mn could supply the necessary amount to produce Mn-oxide fracture fill: (1) Mn-bearing desert varnish that partially goes into solution with rain water and is reprecipitated in fractures; (2) Mnbearing mineral phases, such as Fe-Ti oxides and Clinopyro:enes (Caporuscio et a1. 1982) that contain up to $1 \mathrm{wt} \%$. MnO; and (3) MnO in the original glass of the ash-flow tuffs. More work remains in comparing the Mn content of fresh 


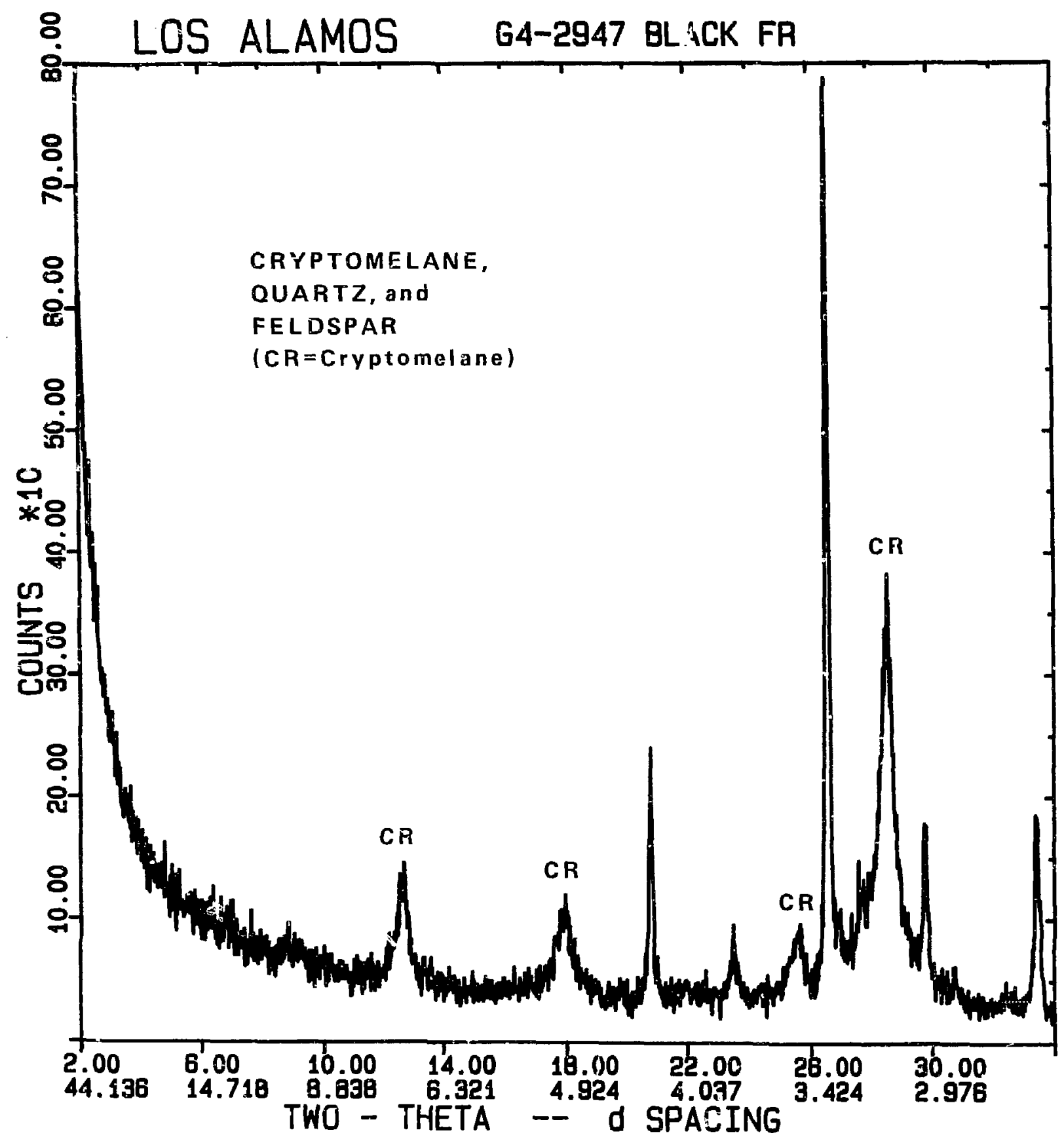

Fig. 3. Representative x-ray diffraction pattern of cryptomelane in USW G-4. 
ash flow tuffs with altered ash-flow tuffs (and their mineral compositions) before the source of Mn-oxide fracture fill can re identified with certainty. However, evaluating the potential significance of $\mathrm{Mn}$ oxides as sorbents at Yucca Mountain is possible based on Zielinski's work. Zielinski (1983) analyzed small (3-g) sampies of bulk tuff for leachable Mn, representing the Mn from sorptive Mn oxides. In samples from the devitirified Topopah Spring Member in USW G-1, these analyses indicate $0.016 \mathrm{wt} \% \mathrm{Mn}$ oxides in the bulk rock. If a repository area of $7 \mathrm{~km}^{2}$ in the Topopah Spring Member is assumed, then a 10-m-thick slab of tuff with a density of $2.25 \mathrm{~g} / \mathrm{cm}^{3}$ directly underlying the repository would contain more than 25,000 metric tons of manganese oxides. This estimate is a minimum, because Mn axides are actually conceritrated along fractures rather than in the bulk rock; adequate estimates of fracture as weil as bulk-rock $M_{n}$-oxide abundances will require study of large samples from exploratory mining at Yucca Mountain. Nevertheless, the waste-element retardation potential of $M n$ oxides at Yucca Mountain is not trivial.

VI. Fe-OXIDE VOLUME CALCULATIONS, AND THEIR LIMITATIONS AS SOLID BUFFERS FOR GROUNDWATER AT YUCCA MOUNTAIN

Using the present estimate of the volume of $\mathrm{Fe}^{2+}$-bearing oxides $(<0.33 \%)$ still at Yucca Mountain, we can now quantify their ability to act as solid buffers of groundwater $\mathrm{Eh}$. The amount of actual $\mathrm{Fe}^{2+}$ oxides left in the Yucca Mountain block is less than 0.16 modal\% (approximately $0.46 \mathrm{wt} \%$ ). Of this, most of the $\mathrm{Fe}^{2+}$ ions in Fe-Ti oxides are isolated from groundwater because they are in densely welded tuffs of low interstitial permeability above the water table. Some of the remaining $\mathrm{Fe}^{2+}$-bearing oxides already exist in reducing environments (sulfide or carbonate bearing). Therefore, the Fe-Ti oxides do not appear to buffer the groundwater below the water table at Yucca Mountain.

Many problems remain unresolved regarding the ability of Fe oxides to buffer groundwater. This is a particular problem in the unsaturated zone where available air could swamp the reducing capacity of ferrous iron in the rocks (Ogard and Kerrisk 1984). Bryond this, several other problems can be enumerated. First, will the volumes present $(0.33 \%$ Fe oxides) have any longlasting capacity for removing oxygen from the groundwater? Second, what are the kinetics of oxide mineral oxidation at low temperatures and how rapid is 74 
the oxidation? Third, based on the kinetics of mineral oxidation and tuff alteration, how long could reduced oxide minerals buffer groundwater? Fourth, is it possible for highly oxidized unsaturated water to oxidize $\mathrm{Fe}^{2+}$-bearing opaques above the static water level? Fifth, is there convection and circulation of the groundwater, or are the oxidizing, reducing, carbonaceous, and sulfide-bearing iluids stratified (convection and mixing of fluids in the groundwater would have significant implications for the ability of mineral phases to oxidize or reduce the grouniwater)? And finally, what effect does the alteration of pristine glass have on groundwater and are enough reduced constituents available in glass to serve as a buffering medium? This last point is particularly important because many meters of fresh glass occur imediately below the potential repository horizon at Yucca Mountain.

VII. Eh BUFFERING POTENTIAL OF $\mathrm{FE}^{2+}$ IN GLASS

The thickress of vitrophyre or vitric tuff in and below the lower Topopah Spring Member varies from abcut $15 \mathrm{~m}$ to $130 \mathrm{~m}$ in drill cores at Yucca Mountain (Bish et al. 1983). This glass could alter, react, dehydrate, and devitriy due to increased temperatures from an overlying repository. $\mathrm{Fe}^{2+}$ in the glass colld oxidize more rapidly during the thermal pulse following repository loading and curing the containment period, or much of the $\mathrm{Fe}^{2+}$ in the glass could remain available for reduction during later passage of water plus waste into the glassy tuff zones during the isolation period of repository history. Whether $\mathrm{Fe}^{2+}$ in $\mathrm{glass}$ is an effective reducing agent is difficult to resolve; however, first we must demonstrate that there is indeed any $\mathrm{Fe}^{2+}$ to be oxidized in these glasses. Table III shows that in fact the only appreciable $\mathrm{Fe}^{2+}$ in bulk-rock samples from drill core USW G-4 occurs in glassy tuff below the devitrified Topopah Spring Member. The glassy tuff in the unsaturated zone below the potential repository horizon apparently provides the closest and most abundant source of ferrous iron. This topic is being addressed through glass thermal stability and oxidation studies.

\section{VIII . CONCLUSIONS}

Volume percentages have been determined for $\mathrm{Fe}^{2+}$ - and Mn-bearing phases at Yucca Mountain, and two conclusions can be made concerning their ability to buffer Eh conditions of the groundwater. First, the available Mn oxides are primarily $\mathrm{Mn}^{4+}$ minerals that have little or no potential for removing oxygen 
TABLE III. FeO (wt\%) IN SAMPLES FROM USW G-4 $4^{\mathrm{a}}$

\begin{tabular}{|c|c|c|}
\hline Devitrifi & $\begin{array}{l}\text { ied Topopah } \\
1089 \mathrm{ft} \\
1190 \mathrm{ft}\end{array}$ & $\begin{array}{l}0 \% \\
0 \%\end{array}$ \\
\hline Zeolite I & $\begin{array}{l}\text { Interval I } \\
1314 \mathrm{ft}\end{array}$ & $0 \%$ \\
\hline Lower Top & $\begin{array}{l}\text { popah Vitrophyre } \\
1330 \mathrm{ft}\end{array}$ & $0.3 \%$ \\
\hline Zeolite & $\begin{array}{c}\text { Interval Il } \\
1438 \mathrm{ft} \\
1544 \mathrm{ft}\end{array}$ & $\begin{array}{l}0 \% \\
0 \%\end{array}$ \\
\hline Central & $\begin{array}{l}\text { Prow Pass Member } \\
1871 \mathrm{ft}\end{array}$ & $0 \%$ \\
\hline Zeolite & $\begin{array}{c}\text { Interval III } \\
2100 \mathrm{ft}\end{array}$ & $0 \%$ \\
\hline Central & $\begin{array}{l}\text { Bu11frog Hember } \\
2516 \mathrm{ft}\end{array}$ & $0 \%$ \\
\hline Zeolite & $\begin{array}{c}\text { Interval Iy } \\
2716 \mathrm{ft} \\
2823 \mathrm{ft}\end{array}$ & $\begin{array}{l}0 \% \\
0 \%\end{array}$ \\
\hline
\end{tabular}

from groundwater; indeed, the potential for higher-valence $M r_{\text {i }}$ to act as an oxidizing agent must also be investigated (Bish and Post 1984; Bartlett 1981; Murray and Dillard 1979; Hem 1978). Second, reduced Fe-Ti oxides have an upper limit of 0.33 vol\%. However, much of that volume is rendered ineffective because the oxides are isolated from groundwater by a low-permeability matrix (densely welded tuff). All groundmass Fe-Ti oxides have already been oxidized to $\mathrm{Fe}^{3+}$, thereby making them unsuitable as solid buffers. Therefore, only a very small percentage of oxide phenocrysts remains as buffering agents. Even at the upper limit of 0.33 vol\%, any freshly exposed solid Fe-oxide buffers could react quickly, leaving the water Eh unbuffered after a short time.

Although no removal of oxygen from groundwater can be expected and oxygen removal by $\mathrm{Fe}$ oxides would at best occur locally and is generally insignificant, a reservoir of $\mathrm{Fe}^{2+}$ remains within glasses beneath the proposed repository horizon at Yucca Mountain. The potential reducing capacity of these glasses is under study, and their real reducing capacity could be modified by accelerated alteration during the thermal pulse of the repository history. Because of these uncertainties and until further data on glass 
interactions are available, it is prudent to assume that the minerals and glasses have little or no capacity for reducing oxygen-rich groundwater at Yucca Mountain.

Finally, we re-emphasize the sorptive potential of Mn oxides resardless of their poor potential as reducing agents. Studies of natural trace-elenent migration show than Mn oxides may have an important role in sorption of heavy metais (for example, U; Zielinski 1978) that are not as effectively sorbed by zeolites as are the alkaline and alkaline-earth elements (Daniels et al. 1982). Calculations based un the data of Zielinski (1983) suggest that the small amounts of Mn oxides at Yuccó Mountain may nevertheless be important retardants when summed up along the flow path. At Yucca Mountain, the selective sorption by Mn oxides cuuld complement sorption by zeolites.

\section{ACKNOWLEDGMENTS}

Preliminary fracture datd for drill cores USW G-4 and USW GU-3 were supplied by $R$. Spengler and $R$. Scott of the US Geological Survey. We greatly appreciate the use of their raw data and their continued advice and support.

We extend special thanks to D. Mann and T. Lucero who prepared high-quality polished thin sactions of the ash-flow tuffs. M. Jones typed the manuscript and illustrations were prepared by $\mathrm{J}$. Tubb. Initial reviews were provided by J. F. Kerrisk and H. Flanner.

\section{REFERENCES}

Bartlett, R. J., "Nonmicrobial Nitrite-to-Nitrate Transformation in Soils," Soil 1 Soc. of Amer. Jour. 45, 1054-1058 (1981).

Bish, D. L. and J. E. Post, "Thermal Behavior of Todorokite and Romanechite," Geol. Soc. Amer. Annual Mtg., Abstracts w/Program, 16, 446 (1984).

Bish, D. L., F. A. Caporuscio, J. F. Copp, B. M. Crowe, J. D. Purson, J. R. Smyth, and R. G. Warren, "Preliminary Stratigraphic and Petrologic Characterization of Core Samples from USW-G1, Yucca Mountain, Nevada," Los Alamos National Laboratory report LA-8840-MS (November 1981).

Bish, D. L., A. E. Ogard, and D. T. Vaniman, "Mineralogy-Petrology and Groundwater Geochemistry of Yucca Mountain Tuffs," in "Scientific Basis for Nuclear W'aste Management VII" (Materials Research Society, Boston, 1983), 283-291.

Bower, N. W., "Simple Spectrophotometric Determination of Ferrous Iron in Twelve French Geochemical Reference Standards," Geostandards N'wsletter $\underline{8}$, 61-62 (1984). 
Byers, F. J. Jr., W. J. Carr, P. P. Orkild, W. D. Quinlivan, and K. A. Sargent, "Volcanic Suites and Related Cauldrons of Timber Mountain-0asis Valley Caldera Complex, Solithern Nevada," US Geol. Surv. Prof. Paper 919, $70(1976)$.

Caporuscio, F., D. Vaniman, D. Bish, D. Broxton, B. Arney, G. Heiken, F. Byers, R. Gooley, E. Semarge, "Petrologic Studies of Drill Cores USW-G2 and UE25b-1H, Yucca Mountain, Nevada," LoS Alamos National Laboratory report LA-9255-MS (July 1982).

Carroll, P. I., F. A. Caporuscio, and D. L. Bish, "Further Description of the Topopah Spring Member of the Paintbrush Tuff in Drill Holes UE-25a\#1 and USW-G1 and the Lithic Rich Tuff in USW-G1, Yucca Mountain, Nevada," LoS Alamos National Laboratory report LA-9000-MS (November 1981).

Christiansen, R. L., P.W. Lipman, W. J. Carr, F. M. Byers, Jr., P. P. Orkild, and K. A. Sargent, "Timber Mountain-0asis Val"ey Caldera Complex of Southern Nevada," Geol. Soc. Am. Bul1. 88, 943-959 (1977).

Daniels, W. R, K. Wolfsberg, R. S. Rundberg, A. E. Ogard, J. F. Kerrisk, C. J. Duffy, et 71., "Summary" Report on the Geochemistry of Yucca Mountain and Environs," Lo: Alamos National Laboratory report LA-9328-MS (December 1982).

Garrells, R. M. and Christ, C. L., Solutions, Minerals and Equilibria (Freeman, Cooper and Co.. San Francisco, 1965).

Haggerty, S. W., "Oxidation of Opaque Mineral Oxides in Basalts," in Oxide Minerals, Min. Soc. Am. Short Course Notes 3 , Hg-1 - Hg-100 (1976a).

Haggerty, S. W., "Opaque Mineral Oxides in Terrestrial Igneous Rocks," in 0xide Minerals, Min. Soc. Am. Short Course Notes 3, Hg-101 - Hg-300 (1976b).

Hem, J. D., "Redox Processes at Surfaces of Manganese 0xide and Their Effects on Aqueous Metal Ions," Chemical Geology 21, 199-218 (1978).

Hildreth, E. W., "The Bishop Tuff. Evidence for the Origin of Compositional Zonation in Silicic Magma Chambers," in Ash-flow tuffs, C. E. Chapin and W. Elston, eds., Geol. Soc. Am. Special Paper 180, 43-75 (1979).

Lipman, P. W., "Iron-Titanium Oxide Phenocrysts in Compositionally Zoned AshFlow Sheets from Southern Nevada," J. Geol. 79, 438 (1971).

Murray, J. W. and J. G. Dillard, "The Oxidation of Cobalt (II) Adsorbed on Manganese Dioxide," Geochim. et Cosmochim. Acta 43, 781-787 (1979).

0gard, A. E. and J. F. Kerrisk, "Groundwater Chemistry Along Flow Paths Between a Proposed Repository Site and the Accessible Environment," Los Alamos National Laboratory report LA-10188-MS (November 1984).

Potter, R. M. and G. R. Rossman, "The Tetravalent Manganese 0xides: Identification, Hydration, and Structural Relationships by Infrared Spectroscopy," Am. Minera 1. 64, 1199-1218 (1979a). 
Potter, R. M. and G. R. Rossman, "Mineralogy of Mariganese Dendrites and Coatings," Am. Mineral. 64, 1219-1226 (1979b).

Vaniman, D., D. Bish, D. Broxton, F. Byers, G. Heiken, B. Carlos, E. Semarge, F. Caporuscio, and R. Gooley, "Variations in Authigenic Mineralogy and Sorptive Zeolite Abundance at Yucca Mountain, Nevada, Based on Studies of Drill Cores USW GU-3 and G-3," Los Alamos National Laboratory report LA-9707-MS (June 1984).

Winograd, J. J. and W. Thordarson, "Hydrogeologic and Hydrochemical Framework, South-Central Great Basin, Nevada - California, with Special Reference to the Nevada Test Site," US Geol. Surv. Prof. Parer 712C (1975).

Zielinski, R. A., "Uranium Abundances and Distribution in Associated Glassy and Crystalline Rhyolites of the Western United States," Geological Soc. of Amer. Bull. 89, 409-414 (1978).

Zielinski, R. A., "Evaluation of Ash-flow Tuffs as Hosts for Radioactive Waste: Criteria based on Selective Leaching of Manganese Oxides," US Geol. Surv. Open File Report 83-480, (1983).

Zielinski, R. A., D. A. Lindsey, and j. N. Rosholt, "The Distribution and Mobility of Uranium in Glassy and Zeolitized Tuff, Keg Mountain Area, Utah, USA," Chem. Geol. 29, 139-162 (1980). 
APPENDIX A

OXIDE ANALYSES 
TABLE A-1. USW G-1 OXIDE MINERAL ANALYSIS (CORE)

\begin{tabular}{|c|c|c|c|c|c|c|c|}
\hline Sample & Average $\left(c_{x}\right)$ & Samp ie & Average & Sample & Averang: & Sample & Average \\
\hline 292 & 3 & 2486 & $\dot{4}$ & 4612 & 5.5 & 5212 & 2.5 \\
\hline 450 & 6 & $255 \overline{5}$ & 6.5 & 4700 & 6 & 5296 & 1.5 \\
\hline 504 & 6 & 2600 & $\dot{\bar{u}} .5$ & 4805 & 5.5 & 5312 & 1 \\
\hline 619 & 5.5 & 2541 & 6.5 & 4875 & 5 & 5348 & 3 \\
\hline 722 & 2.5 & 2689 & 6 & 4912 & 5 & 5412 & 1 \\
\hline 757 & 5 & 2790 & 5.5 & 4998 & 5 & 5498 & 4 \\
\hline 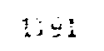 & 4 & 2854 & 5.5 & 5026 & 5 & 5637 & 2 \\
\hline 1240 & 6 & 2868 & 6.5 & 5093 & 5 & 5679 & 1 \\
\hline 1286 & 4 & 2901 & 6.5 & 5126 & 5 & 5746 & 4 \\
\hline 1291 & 1.5 & 2937 & 6.5 & 5167 & $\hat{3}$ & 5847 & 4 \\
\hline 1392 & 4.5 & 3001 & 6 & & & 5947 & 2.5 \\
\hline 1436 & 6 & 3116 & 6.5 & & & & \\
\hline 1561 & 5.5 & 3196 & 6.5 & & & & \\
\hline 1639 & 6.5 & 3258 & 6.5 & & & & \\
\hline 1774 & 6 & $33 ? 1$ & 1.2 & & & & \\
\hline 1819 & 5 & 3371 & 1.3 & & & & \\
\hline 1854 & 5 & 3500 & 1.5 & & & & \\
\hline 1883 & 4 & 3598 & 2.5 & & & & \\
\hline 1982 & 2 & 3658 & 2.5 & & & & \\
\hline 2083 & 6 & 3706 & 2.5 & & & & \\
\hline 2166 & 6.5 & 3850 & 2.5 & & & & \\
\hline 2233 & 6.5 & 3940 & 7 & & & & \\
\hline 2247 & 6.5 & 3997 & 14 & & & & \\
\hline 2289 & 6 & 4095 & 6 & & & & \\
\hline 2290 & 6 & 4208 & 5.5 & & & & \\
\hline 2318 & 6 & 4295 & 5.5 & & & & \\
\hline 2363 & 6 & 4341 & 6 & & & & \\
\hline 2410 & 6.5 & 4400 & 5.5 & & & & \\
\hline 2436 & 4 & 4503 & 6 & & & & \\
\hline 2476 & 6 & & & & & & \\
\hline
\end{tabular}


TABLE A-2. USW G-2 OXIDE MINERAL ANALYSIS (CORE)

\begin{tabular}{|c|c|c|c|c|c|}
\hline Sample & Average & Range & Sample & Average & Range \\
\hline 304 & $c_{1}$ & $c_{1}$ & 1634 & $c_{3.0}$ & $c_{1}-c_{5}$ \\
\hline 331 & $c_{1}$ & $c_{1}$ & 1664 & $c_{5.5}$ & $c_{4}-c_{6}$ \\
\hline 338 & $c_{2.2}$ & $c_{1}-c_{4}$ & 1691 & $c_{6.4}$ & $c_{6}-c_{7}$ \\
\hline 358 & $c_{2.0}$ & $c_{1}-c_{4}$ & 1745 & $c_{5.3}$ & $c_{4}-c_{7}$ \\
\hline 395 & $c_{2.4}$ & $c_{1}-c_{5}$ & 1752 & $c_{5.1}$ & $c_{4}-c_{6}$ \\
\hline 501 & $c_{3.2}$ & $c_{3}-c_{4}$ & 1798 & $c_{5.2}$ & $c_{4}-c_{7}$ \\
\hline 547 & $c_{1.9}$ & $c_{1}-c_{3}$ & 1848 & $C_{4.6}$ & $c_{3}-c_{7}$ \\
\hline 561 & $c_{3}$ & $c_{1}-c_{4}$ & 1899 & $c_{5.2}$ & $c_{4}-c_{6}$ \\
\hline 584 & $c_{3.4}$ & $c_{1}-c_{5}$ & 1952 & $c_{5.9}$ & $c_{4}-c_{7}$ \\
\hline 627 & $C_{2.4}$ & $c_{1}-c_{5}$ & 2001 & $C_{E .8}$ & $c_{4}-c_{7}$ \\
\hline 675 & $c_{2,3}$ & $c_{1}-c_{6}$ & 2078 & $C_{5.9}$ & $c_{3}-c_{7}$ \\
\hline 723 & $c_{1.7}$ & $c_{1}-c_{4}$ & 2158 & $c_{6.3}$ & $c_{3}$ \\
\hline 734 & $c_{3.4}$ & $c_{1}-c_{6}$ & 2248 & $C_{6.3}$ & $c_{5}-C_{7}$ \\
\hline 762 & $\mathrm{C}_{2}$ & $c_{1}-c_{4}$ & 2325 & $C_{6.8}$ & $c_{G}-c_{7}$ \\
\hline 770 & $c_{2}$ & $c_{1}-c_{4}$ & 2430 & $C_{6.6}$ & $c_{6}-c_{7}$ \\
\hline 822 & $C_{6}$ & $c_{3}-c_{7}$ & 2528 & $C_{6.6}$ & $c_{6}-c_{7}$ \\
\hline 855 & $c_{5.6}$ & $C_{4}-C_{6}$ & 2667 & $C_{6.0}$ & $c_{4}-c_{7}$ \\
\hline 898 & $c_{6}$ & $c_{6}-c_{7}$ & 2744 & $C_{4} 6$ & $c_{1}-c_{7}$ \\
\hline 921 & $c_{5.2}$ & $c_{3}-c_{7}$ & 2820 & $C_{5.3}$ & $c_{2}-c_{6}$ \\
\hline 951 & $c_{3.2}$ & $c_{1}-c_{7}$ & 2869 & $c_{5.8}$ & $c_{5}-c_{7}$ \\
\hline 984 & $c_{2.3}$ & $c_{1}-c_{7}$ & 2887 & $c_{5.7}$ & $c_{4}-c_{7}$ \\
\hline 1032 & $C_{5.2}$ & $c_{1}-c_{7}$ & 2950 & $c_{6.0}$ & $c_{6}-c_{7}$ \\
\hline 1072 & $\mathrm{C}_{5.1}$ & $c_{2}-c_{7}$ & 2970 & $c_{6.1}$ & $c_{5}-c_{7}$ \\
\hline 1133 & $c_{4.2}$ & $c_{1}-c_{6}$ & 3037 & $c_{5.8}$ & $c_{4}-C_{7}$ \\
\hline 1178 & $C_{6}$ & $c_{5}-C_{7}$ & 3067 & $C_{5.0}$ & $c_{4}-c_{6}$ \\
\hline 1235 & $c_{6.3}$ & $c_{1}-c_{7}$ & 3192 & $c_{3.7}$ & $c_{1}-c_{7}$ \\
\hline 1281 & $c_{5.2}$ & $c_{2}-c_{7}$ & $3250^{\mathrm{d}}$ & $c_{5.3}$ & $c_{1}-c_{7}$ \\
\hline 1331 & $C_{5.2}$ & $c_{1}-c_{7}$ & 3308 & $C_{6.7}$ & $c_{6}-c_{7}$ \\
\hline 1382 & $C_{3.8}$ & $c_{1}-c_{7}$ & 3360 & $c_{3.8}$ & $c_{3}$ \\
\hline 1420 & $c_{5.3}$ & $c_{3}-c_{6}$ & $3416^{\mathrm{a}}$ & $c_{5.2}$ & $c_{1}-c_{7}$ \\
\hline 1461 & $C_{6.1}$ & $c_{4}-c_{7}$ & $3492^{a}$ & $\mathrm{C}_{3.0}$ & $c_{1}-c_{7}$ \\
\hline $158 E$ & $c_{5.1}$ & $c_{1}-c_{7}$ & $3541^{a}$ & $c_{4.0}$ & $c_{1}-c_{7}$ \\
\hline
\end{tabular}


TABLE A-2 (cort)

\begin{tabular}{|c|c|c|c|c|c|}
\hline Sample & Average & Range & Sample & Average & Rànge \\
\hline $3671^{a}$ & $c_{a}$ & $c_{1}-c_{7}$ & 4924 & $c_{5,2}$ & $c_{3}=$ \\
\hline $3772^{a}$ & $c_{6,7}$ & $c_{5}-c_{7}$ & 5017 & $c_{1.3}$ & $c_{1}-$ \\
\hline $3875^{a}$ & $c_{5}^{0}$ & $c_{4}-c_{7}$ & 5144 & $c_{5.3}$ & \\
\hline $3933^{a}$ & $c_{6.9}^{3.5}$ & $c_{6}-c_{7}$ & 5206 & & \\
\hline $4005^{d}$ & $c_{1.7}^{0.7}$ & $c_{1}-c_{5}$ & $5305^{\circ}$ & $c_{5}$ & \\
\hline $4090^{a}$ & $c_{1.5}$ & $c_{1}-c_{4}$ & 5379 & & \\
\hline 4167 & $c_{2.9}$ & $c_{1}-c_{7}$ & 5493 & $c_{4}$ & 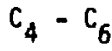 \\
\hline $4199^{a}$ & $c_{1.3}$ & $c_{1}-c_{2}$ & 5596 & $c_{4.3}$ & \\
\hline $4209^{d}$ & $c_{2.0}$ & $c_{1}-c_{5}$ & 56.38 & $c_{3.9}$ & \\
\hline 4267 & $c_{3.5}$ & $c_{1}-c_{5}$ & 5657 & $c_{3.6}$ & $c_{1}-$ \\
\hline 4329 & $c_{5.5}$ & $c_{E}-c_{6}$ & 5696 & $c_{3}$ & \\
\hline 4467 & $c_{5.5}$ & $c_{5}-c_{6}$ & 5890 & $c_{1}$ & \\
\hline 4570 & $c_{5.8}$ & $c_{5}-c_{7}$ & 5885 & $c_{1}$ & $c_{1}$ \\
\hline 4788 & $c_{5.5}$ & $c_{4}-c_{7}$ & 5895 & $c_{2.6}$ & \\
\hline 4805 & $c_{5.4}$ & $c_{5}-c_{6}$ & 5926 & $c_{2.7}$ & \\
\hline 4838 & $c_{5.1}$ & $c_{z}-c_{\delta}$ & 5951 & $c_{2.5}$ & $c_{1}$ \\
\hline & & & 5992 & $\mathrm{C}_{3.6}$ & \\
\hline
\end{tabular}

a Sulfides present. 
TABLE A-3. USW GU-3 OXIDE MINERAL ANALYSIS (CORE)

\begin{tabular}{|c|c|c|c|c|c|}
\hline Sample & Average & Range & Sample & Average & Range \\
\hline 31 & 4.6 & $c_{3}=c_{7}$ & 1303 & 3.4 & $c_{2}-c_{6}$ \\
\hline 45 & 5.9 & $c_{2}-c_{7}$ & 1322 & 3,6 & $c_{2}-c_{6}$ \\
\hline 78 & 5.8 & $c_{4}-c_{7}$ & 1394 & 4.4 & $c_{3}-c_{6}$ \\
\hline 103 & 4.8 & $c_{1}-c_{6}$ & 1439 & 4.3 & $c_{2}-c_{6}$ \\
\hline 245 & 4.5 & $c_{1}-c_{7}$ & 1498 & 3.1 & $c_{1}-c_{7}$ \\
\hline 303 & 5.2 & $c_{4}-c_{6}$ & 1537 & 2.6 & $r_{1}-c$ \\
\hline 316 & 5.2 & $C_{5}-c_{6}$ & 1571 & 4.8 & $c_{4}-c_{7}$ \\
\hline 341 & 5.7 & $c_{5}-c_{7}$ & 1598 & 5.3 & $c_{1}-c_{7}$ \\
\hline 356 & 3.4 & $c_{2}-c_{5}$ & 1603 & 6.0 & $\mathrm{c}_{\epsilon}$ \\
\hline 376 & 2.2 & $c_{2}-c_{3}$ & 1653 & 6.8 & $c_{6}-c$ \\
\hline 410 & 5.6 & $c_{4}-c_{7}$ & 1709 & 7.0 & $c_{7}$ \\
\hline 424 & 6.3 & $c_{4}-c_{7}$ & 1744 & 6.8 & $c_{6}-c_{7}$ \\
\hline 430 & 3.9 & $c_{3}-c_{5}$ & 1874 & 5.2 & $c_{2}-c_{7}$ \\
\hline 465 & 6.5 & $c_{5}-c_{7}$ & 1986 & 5.6 & $c_{5}-c_{7}$ \\
\hline 482 & 6.3 & $c_{5}-c_{7}$ & 1993 & 5.3 & $c_{2}-c_{7}$ \\
\hline 525 & 6.4 & $c_{6}-c_{7}$ & 2070 & 6.2 & $c_{6}-c_{7}$ \\
\hline 633 & 4.2 & $c_{1}-c_{7}$ & 2138 & 6.0 & $c_{5}-c_{7}$ \\
\hline 769 & 5.3 & $c_{5}-c_{6}$ & 2177 & 6.2 & $c_{6}-c_{7}$ \\
\hline 954 & 4.0 & $c_{1}-c_{6}$ & 2189 & 5.8 & $c_{5}-c_{7}$ \\
\hline 1130 & 3.7 & $c_{1}-c_{6}$ & 2369 & 4.9 & $c_{4}-c_{6}$ \\
\hline 1175 & 4.0 & $c_{1}-c_{6}$ & 2467 & 4.7 & $c_{4}-c_{6}$ \\
\hline 1195 & 2.7 & $c_{1}-c_{5}$ & 2577 & 4.6 & $c_{3}-c_{6}$ \\
\hline 1227 & 2.2 & $c_{1}-c_{5}$ & & & \\
\hline
\end{tabular}


TABLE A-4. USW G-3 OXIDE MINERAL ANALYSIS (CORE)

\begin{tabular}{|c|c|c|c|c|c|}
\hline Sample & Average & Rarıge & Sample & Average & Range \\
\hline 2615 & 4.9 & $c_{4}-c_{6}$ & 3672 & 6.0 & $c_{6}$ \\
\hline 2656 & 5.3 & $c_{3}-c_{7}$ & $3759^{a}$ & 3.1 & $c_{2}-c_{4}$ \\
\hline 2695 & 5.7 & $c_{5}-c_{7}$ & $3854^{\mathrm{a}}$ & 3.9 & $c_{1}-c_{7}$ \\
\hline 2727 & 6.2 & $c_{5}-c_{7}$ & $4008^{d}$ & 4.3 & $c_{3}-c_{5}$ \\
\hline 2914 & 6.3 & $c_{6}-c_{7}$ & $4240^{a}$ & 5.1 & $c_{4}-c_{7}$ \\
\hline 3004 & 5.8 & $c_{5}-c_{7}$ & $4297^{a}$ & 5.5 & $c_{5}-c_{6}$ \\
\hline 3045 & 6.2 & $c_{6}-c_{7}$ & $44.16^{\mathrm{a}}$ & 5.7 & $c_{5}-c_{6}$ \\
\hline 3113 & 6.0 & $c_{5}-c_{7}$ & $1423^{\mathrm{d}}$ & 5.5 & $c_{1}-c_{7}$ \\
\hline 3164 & 6.3 & $c_{6}-c_{7}$ & $4568^{\mathrm{a}}$ & 5.1 & $c_{2}-c_{6}$ \\
\hline 3207 & 6.2 & $c_{6}-c_{7}$ & 4600 & 5.8 & \\
\hline 3226 & 6.2 & $c_{5}-c_{7}$ & $4708^{\mathrm{a}}$ & 5.7 & $c_{5}$ \\
\hline 3310 & 6.2 & $c_{5}-c_{7}$ & $4756^{\mathrm{a}}$ & 4.0 & $c_{1}$ \\
\hline 3475 & 6.2 & $c_{5}-c_{7}$ & $4906^{a}$ & 4.0 & \\
\hline 3589 & 6.0 & $c_{5}-c_{7}$ & 5014 & 5.3 & $c_{5}-c_{6}$ \\
\hline
\end{tabular}

a Sulfides present. 
TABLE A-5. USW G-4 OXIDE MINERAL ANALYSIS (CORE)

\begin{tabular}{|c|c|c|c|c|c|}
\hline Sainple & $\begin{array}{c}\text { Oxidation } \\
\text { Average }\end{array}$ & $\begin{array}{c}\text { Oxidation } \\
\text { Range }\end{array}$ & Sample & $\begin{array}{l}\text { Oxidation } \\
\text { Average }\end{array}$ & $\begin{array}{l}\text { Oxidation } \\
\text { Range }\end{array}$ \\
\hline$G-4-72$ & 4.9 & $c_{3}-c_{6}$ & 1392 & 4.4 & $c_{1}-c_{7}$ \\
\hline 107 & 5.6 & $c_{3}-c_{7}$ & 1419 & 4.2 & $c_{1}-c_{7}$ \\
\hline 123 & 4.1 & $c_{2}-c_{7}$ & 1432 & 4.5 & $c_{3}-c_{7}$ \\
\hline 147 & 4.3 & $c_{3}-c_{7}$ & $1432(2)$ & 4.1 & $c_{2}-c_{7}$ \\
\hline 148 & 6.4 & $c_{3}-c_{7}$ & 1438 & 5.4 & $c_{2}-c_{7}$ \\
\hline 159 & 3.5 & $c_{1}-r_{6}$ & 1470 & 5.1 & $c_{4}-c_{6}$ \\
\hline 170 & 4.1 & $c_{2}-c_{7}$ & 1544 & 5.8 & $c_{5}-c_{7}$ \\
\hline 220 & 4.3 & $c_{3}-c_{6}$ & $1544(2)$ & 5.5 & $c_{5}-c_{6}$ \\
\hline 231 & 5.7 & $c_{5}-c_{7}$ & 1602 & 6.4 & \\
\hline $236^{2}$ & 6.3 & $c_{5}-c_{7}$ & 1685 & 6.1 & $c_{3}-c_{7}$ \\
\hline 241 & 7.0 & $c_{7}$ & 1707 & 6.9 & $c_{6}-c_{7}$ \\
\hline 383 & 4.4 & $c_{2}-c_{7}$ & $1702(2)$ & 7.0 & $c_{7}$ \\
\hline 410 & 4.5 & $c_{2}-c_{6}$ & 1734 & 5.2 & $c_{4}-c_{7}$ \\
\hline 416 & 5.8 & $c_{3}-c_{7}$ & 1762 & 5.8 & $c_{1}-c_{7}$ \\
\hline 447 & 6.4 & $c_{6}-c_{7}$ & 1763 & 3.9 & $c_{2}-c_{5}$ \\
\hline 514 & 5.6 & $c_{1}-c_{7}$ & 1780 & 4.5 & $c_{4}-c_{6}$ \\
\hline 556 & 5.8 & $c_{5}-c_{7}$ & 1872 & 4.2 & $c_{3}-c_{5}$ \\
\hline 625 & 5.5 & $c_{4}-c_{7}$ & 1989 & 6.0 & $c_{5}-c_{7}$ \\
\hline 677 & 5.5 & $c_{5}-c_{7}$ & 2039 & 5.7 & $c_{5}-c_{7}$ \\
\hline $692^{b}$ & 1.2 & $c_{1}-c_{2}$ & 2090 & 5.4 & $c_{5}-c_{6}$ \\
\hline 746 & 5.5 & $c_{4}-c_{6}$ & 2132 & 5.5 & $c_{4}-c_{7}$ \\
\hline 817 & 4.9 & $C_{4}-C_{6}$ & 2202 & 6.1 & $c_{5}-c_{7}$ \\
\hline $934^{c}$ & 5.7 & $c_{1}-c_{7}$ & 2227 & 6.6 & \\
\hline 1026 & 3.7 & $c_{1}-c_{7}$ & 2239 & 5.9 & $c_{4}-c_{7}$ \\
\hline 1089 & 5.0 & $c_{3}-c_{6}$ & 2285 & 5.8 & $c_{5}-c_{6}$ \\
\hline 1117 & 4.9 & $c_{3}-c_{6}$ & 2355 & 5.3 & $c_{4}-c_{6}$ \\
\hline 1190 & 3.7 & $c_{1}-c_{6}$ & 2534 & 5.6 & $c_{5}-c_{6}$ \\
\hline 1244 & 4.8 & $c_{2}-c_{6}$ & 2599 & 5.8 & $C_{5}-C_{7}$ \\
\hline 1282 & 4.2 & $c_{1}-c_{6}$ & 2681 & 4.9 & $-c_{6}$ \\
\hline 1299 & 3.4 & $c_{1}-c_{6}$ & 2731 & 4.8 & $c_{4}-c_{7}$ \\
\hline 1311 & 2.2 & $c_{1}-c_{4}$ & 2738 & 5.8 & $c_{5}-c_{7}$ \\
\hline 1314 & 2.1 & $c_{1}-c_{3}$ & 2755 & 5.6 & $c_{5}-c_{7}$ \\
\hline 1331 & 1.5 & $c_{1}-c_{2}$ & 2791 & 5.9 & $c_{5}-c_{7}$ \\
\hline $1342^{d}$ & 2.3 & $c_{2}-c_{4}$ & 2841 & 6.5 & $c_{5}-c_{7}$ \\
\hline 1381 & 5.9 & $c_{4}-C_{4}$ & 3001 & 6.1 & $C_{5}-c_{5}$ \\
\hline
\end{tabular}

\footnotetext{
One pyrhottite grain.

b Sulfide in one magnette grain.

c Mostiy $i_{5-7}$ and one $c_{1}$.

d Sulfide in one magnetite grain.
} 
TABLE A-6. USW H-6 OXIDE MINERAL ANALYSIS (CORE)

\begin{tabular}{|c|c|c|}
\hline Sample & $\begin{array}{c}\text { Dxidation } \\
\text { Average }\end{array}$ & $\begin{array}{c}\text { Oxidation } \\
\text { Range }\end{array}$ \\
\hline 1092 & 6.2 & $c_{5}-c_{7}$ \\
\hline 1129 & 5.8 & $c_{4}-c_{7}$ \\
\hline 1149 & 4.4 & $c_{1}-c_{6}$ \\
\hline 1166 & 4.3 & $c_{2}-c_{7}$ \\
\hline 1368 & 4.9 & $c_{4}-c_{7}$ \\
\hline 1376 & 5.4 & $c_{4}-c_{7}$ \\
\hline 1381 & 5.4 & $c_{3}-c_{7}$ \\
\hline 1426 & 5.9 & $c_{5}-c_{7}$ \\
\hline 1512 & 6.0 & $c_{5}-c_{7}$ \\
\hline 1671 & 5.8 & $c_{3}-c_{7}$ \\
\hline 1679 & 5.2 & $c_{2}-c_{7}$ \\
\hline 1829 & 6.6 & $c_{6}-c_{7}$ \\
\hline 2051 & 6.5 & $c_{6}-c_{7}$ \\
\hline 2354 & 5.7 & $c_{4}-c_{7}$ \\
\hline 2865 & 6.3 & $c_{5}-c_{7}$ \\
\hline 3003 & 4.5 & $c_{3}-c_{6}$ \\
\hline 3188 & 5.4 & $c_{4}-c_{7}$ \\
\hline 3605 & 2.6 & $C_{1}-c_{4}$ \\
\hline $3806^{\mathrm{a}}$ & 5.5 & $c_{5}-c_{6}$ \\
\hline
\end{tabular}

a Minor suifides (oyrrhotite?) present in phenocrysts of USW H-6-3806. 
TABLE A-7. UE-25p\#1 OXIDE MINERAL ANALYSIS (CUTTINGS, SIDEWALL SAMPLES AND CORE)

\begin{tabular}{|c|c|c|c|}
\hline Si pie & $\begin{array}{l}\text { Oxfdation } \\
\text { Average }\end{array}$ & $\begin{array}{l}\text { Oxidation } \\
\text { Range }\end{array}$ & Comments \\
\hline 120 & 5.4 & $c_{1}=c_{7}$ & \\
\hline 210 & 4.8 & $c_{1}-c_{7}$ & \\
\hline 270 & 1.5 & $c_{1}-c_{2}$ & a Fe-Tf-oxide phenocrysts \\
\hline 290 & 1.1 & $c_{1}-c_{2}$ & $4 \mathrm{Fe}-\mathrm{Tl}$-oxtde phenocrysts \\
\hline 420 & 6.6 & $c_{6}-c_{7}$ & \\
\hline 580 & 4.9 & $c_{4}-c_{5}$ & 7 Fe-Ti-oxide phenocrysts \\
\hline 620 & 4.2 & $c_{3}-c_{6}$ & $5 \mathrm{Fe}-\mathrm{TI}$-oxide phenocrysts \\
\hline 310 & 4.9 & $c_{3}-c_{6}$ & \\
\hline 1050 & 4.0 & $c_{3}-c_{5}$ & $5 \mathrm{Fe}-\mathrm{Ti}$-oxide phenocrysts \\
\hline 1150 & 5.4 & $c_{5}-c_{6}$ & $8 \mathrm{Fe}-\mathrm{Tl}$-oxide phenocrysts \\
\hline 1250 & 5.5 & $c_{5}-c_{6}$ & 4 Fe-Ti-oxide phenocrysts \\
\hline 1270 & 5.3 & $c_{5}-c_{6}$ & $4 \mathrm{Fe}-\mathrm{Ti}$-oxide phenocrysts \\
\hline $1290^{\mathrm{a}}$ & 6.0 & $c_{6}$ & $4 \mathrm{Fe}-\mathrm{Ti}$-oxide phenocrysts \\
\hline$: 350$ & 5.0 & $C_{5}$ & 4 Fe-Ti-oxide phenocrysts \\
\hline $1400^{a}$ & 7.0 & $\mathrm{C}_{7}$ & \\
\hline $1420^{\circ}$ & 6.0 & $c_{1}-c_{7}$ & \\
\hline $1470^{a}$ & 5.4 & $c_{4}-c_{7}^{\prime}$ & \\
\hline 1598 & 6.3 & $c_{4}-c_{7}$ & \\
\hline 1650 & 6.7 & $c_{6}-c_{7}$ & $7 \mathrm{Fe}-\mathrm{Tl}$ oxtde phenocrysts \\
\hline 1700 & 4.7 & $c_{4}-c_{6}$ & \\
\hline 1740 & 5.6 & $c_{5}-c_{7}$ & \\
\hline 1800 & 5.9 & $c_{5}-c_{7}$ & \\
\hline 1840 & 5.5 & $c_{5}-C_{6}$ & \\
\hline 1930 & 5.0 & $c_{4}-c_{6}$ & \\
\hline 2000 & 5.5 & $c_{5}-c_{6}$ & \\
\hline 2220 & 5.5 & $c_{5}-c_{7}$ & \\
\hline 2250 & 5.8 & $C_{5}-C_{7}$ & \\
\hline 2290 & 5.5 & $c_{5}-c_{7}$ & \\
\hline 2380 & 5.4 & $c_{5}-c_{6}$ & $7 \mathrm{Fe}-\mathrm{Ti}$ oxide phenocrysts \\
\hline 2520 & 5.8 & $c_{5}-c_{6}$ & \\
\hline 2580 & 5.6 & $c_{4}-c_{7}$ & \\
\hline
\end{tabular}


TABLE A-7 (cont)

\begin{tabular}{|c|c|c|c|}
\hline Sample & $\begin{array}{l}\text { Oxidation } \\
\text { Average }\end{array}$ & $\begin{array}{l}\text { Oxidation } \\
\text { Range }\end{array}$ & Comments \\
\hline 2640 & 5.7 & $c_{5}-c_{7}$ & \\
\hline 2660 & 6.3 & $c_{5}-c_{7}$ & \\
\hline 2760 & 6.1 & $c_{1}-c_{7}$ & \\
\hline 2900 & 5.0 & $c_{4}-c_{6}$ & \\
\hline 2950 & 5.5 & $c_{4}-c_{7}$ & \\
\hline 3170 & 5.3 & $c_{5}-c_{6}$ & \\
\hline 3240 & 5.0 & $c_{5}-c_{7}$ & \\
\hline 3330 & 5.3 & $c_{4}-c_{6}$ & \\
\hline 3453.3 & 5.1 & $c_{5}-c_{6}$ & \\
\hline 3560 & 5.0 & $c_{4}-c_{6}$ & \\
\hline 3570 & 4.4 & $c_{4}-c_{5}$ & \\
\hline 3600 & 5.7 & $c_{5}-c_{6}$ & \\
\hline 3640 & 5.5 & $c_{4}-c_{6}$ & \\
\hline 3660 & 4.5 & $c_{4}-c_{5}$ & \\
\hline 3670 & 4.5 & $c_{4}-c_{5}$ & \\
\hline 3730 & 2.3 & $c_{1}-c_{3}$ & \\
\hline $3913^{b}$ & 6.0 & $c_{5}-c_{7}$ & \\
\hline $\begin{array}{l}3916.8^{\circ} \\
3928^{b}\end{array}$ & 5.7 & $c_{5}-c_{7}$ & Sulfides only \\
\hline 3970 & 5.7 & $c_{5}-c_{6}$ & \\
\hline 3990 & 6.2 & $c_{5}-c_{7}$ & \\
\hline
\end{tabular}


TABLE A-8. UE-25a\#1 OXIDE MINERAL ANALYSIS (CORE)

\begin{tabular}{|c|c|c|}
\hline Sample & Average & Range \\
\hline YM33 & $c_{5}$ & $c_{4}-c_{6}$ \\
\hline YM45 & $c_{4}$ & $c_{3}-c_{5}$ \\
\hline YM48 & $c_{6}$ & \\
\hline YM49 & C5 & $i_{4}$ \\
\hline YM54 & $c_{5}$ & $C_{4}$ \\
\hline
\end{tabular}

TABLE A-9. UE-25b\#1 OXIDE MINERAL ANALYSIS (CORE)

\begin{tabular}{|c|c|c|c|c|c|}
\hline Sample & Average & Range & Sample No. & Average & Range \\
\hline 2402 & $c_{5.6}$ & $c_{5}-c_{6}$ & 3225 & $c_{5.8}$ & $c_{5}-c_{6}$ \\
\hline 2525 & $c_{6.4}$ & $c_{6}-c_{7}$ & $3 i \cdot$ & $C_{6.0}$ & $c_{6}$ \\
\hline 2596 & $c_{6.5}$ & $c_{6}-c_{7}$ & 3322 & $c_{6.2}$ & $c_{6}-c_{7}$ \\
\hline 2737 & $c_{6.7}$ & $c_{6}-c_{7}$ & $.3393^{\mathrm{a}}$ & $c_{1.5}$ & $c_{1}-c_{2}$ \\
\hline 2832 & $c_{6.6}$ & $c_{5}-c_{7}$ & $3469^{a}$ & - & \\
\hline 2855 & $c_{6.1}$ & $c_{5}-c_{7}$ & $3506^{a}$ & - & \\
\hline 2879 & $c_{5.5}$ & $c_{4}-c_{7}$ & $377 \mathrm{iA}^{\mathrm{a}}$ & $c_{4}$ & 1 grain \\
\hline 2919 & $c_{6.4}$ & $c_{6}-c_{7}$ & $3571 \mathrm{~B}^{\mathrm{a}}$ & $c_{1}$ & l grain \\
\hline 2953 & $c_{5.8}$ & $c_{5}-c_{6}$ & $3660^{\mathrm{a}}$ & $c_{1}$ & $c_{1}$ \\
\hline 3050 & $c_{6.0}$ & $c_{5}-c_{7}$ & $3767^{\mathrm{a}}$ & $c_{1.2}$ & $c_{1}-c_{2}$ \\
\hline 3095 & $c_{5.3}$ & $C_{5}-C_{6}$ & $3835^{\mathrm{a}}$ & $c_{1.2}$ & $c_{1}-c_{2}$ \\
\hline 3018 & $c_{6.1}$ & $c_{5}-c_{7}$ & $3902^{\mathrm{a}}$ & - & \\
\hline 3163 & $c_{5.7}$ & $c_{5}-c_{7}$ & $3910^{\mathrm{a}}$ & $c_{1}$ & 1 grain \\
\hline 3185 & $c_{5.7}$ & $c_{4}-c_{7}$ & $3956^{\mathrm{a}}$ & $c_{2}$ & $c_{1}-c_{3}$ \\
\hline 3196 & $c_{6.0}$ & $c_{5}-c_{7}$ & $3988^{a}$ & $c_{1.7}$ & \\
\hline
\end{tabular}

